\title{
Estimating carbon dynamics in forest carbon pools under IPCC standards in South Korea using CBM-CFS3
}

\author{
Moonil Kim ${ }^{(1-2)}$, \\ Woo-Kyun Lee ${ }^{(1)}$, \\ Werner A Kurz ${ }^{(3)}$, \\ Doo-Ahn Kwak ${ }^{(4)}$, \\ Scott Morken ${ }^{(3)}$, \\ Carolyn E Smyth ${ }^{(3)}$, \\ Donghoon Ryu ${ }^{(5)}$
}

\begin{abstract}
The main objective of this study was to estimate past and future dynamics of forest carbon pools in South Korea, as classified by the Intergovernmental Panel on Climate Change (IPCC) Good Practice Guidance (GPG) and to test the Carbon Budget Model of the Canadian Forest Sector 3 (CBM-CFS3). Inventory data required in CBM-CFS3 were extracted from Korea's $3^{\text {rd }}$ Forest Type Map. The site index in the inventory data was estimated through regression models developed using $5^{\text {th }}$ National Forest Inventory (NFI) data with 4000 plots. Necessary yield tables to a stand age of over 100 years, stratified by species, were prepared through the estimation of volume per ha with tree species, site index and stand age. We considered thinning and cutting regulations for sustainable forest management announced by the Korean Forest Service and that the forest area was constant over from 1992 to 2092. We estimated the carbon stocks and their changes of aboveground (AGB) and belowground (BGB) biomass, litter (L), dead wood (DW), and soil organic matter (SOM). Validation was conducted based on the $5^{\text {th }} \mathrm{NFI}$ and statistical data. Our results showed that the carbon content of the total forest area increased from $509.7 \mathrm{Tg} \mathrm{C}$ to 1007.3 $\mathrm{Tg} \mathrm{C}$ at a rate of 11.8 $\mathrm{Tg} \mathrm{C} \mathrm{yr}^{-1}$ during 1992-2034. Results also showed that AGB, BGB, DW, L and SOM changed from 54.6, 30.2, 15.9, 43.6, and 373.9 $\mathrm{Tg} C$ in 1992 to $455.6,100.77,32.89,65.46$, and $369.2 \mathrm{Tg} C$ in 2034 , respectively. However, the amount of forest carbon was projected to decrease due to large increases in harvest rates as most of the forest reaches the legislated cutting age during 2035-2045. Our simulation estimated that by 2045 AGB, BGB, and SOM decreased to $347.8,78.2$, and $368.9 \mathrm{Tg} \mathrm{C}$, respectively, while DW and $L$ increased to 46.8 and $89.1 \mathrm{Tg} C$, respectively. The carbon content of the total forested area starts to stabilize after 2045 as the annual stand growth gradually decreases. Finally in 2092, the carbon content of AGB, BGB, DW, $L$, and SOM was estimated as $422.3,93.9,31.2,63.0$, and $365.1 \mathrm{Tg} C$, respectively. Through harvesting, over the 100 year period more than $200 \mathrm{Tg}$ C were transferred from South Korea's forests to meet demands for timber, fiber and energy. Good agreement between model results, NFI data and independent studies, demonstrates the applicability of CBM-CFS3 for estimating past and future forest carbon budgets in South Korean forests and for exploring forest management activity impacts in managed forests.
\end{abstract}

Keywords: CBM-CFS3, Carbon Dynamics, Forest Management, National Forest Inventory, Forest Type Map

\section{Introduction \\ Climate change has led to the global reg- ulation of industrial development in an ef- fort to restrict carbon dioxide $\left(\mathrm{CO}_{2}\right)$ emis- \\ sions, in both advanced and developing countries. Globally, forests are a major car- bon (C) sink responsible for removing from the atmosphere $29 \%$ of anthropogenic C}

$\square$ (1) Division of Environmental Science and Ecological Engineering, Korea University, 136713 Seoul (Republic of Korea); (2) International Institute for Applied Systems Analysis, A-2361 Laxenburg (Austria); (3) Natural Resources Canada, Canadian Forest Service, 506 West Burnside Road, V8Z 1 M5 Victoria, British Columbia (Canada); (4) Forest Welfare Division, National Institute of Forest Science, 136-712 Seoul (Republic of Korea); (5) Department of Climate Environment, Korea University, 136-713 Seoul (Republic of Korea)

@ Woo-Kyun Lee (leewk@korea.ac.kr)

Received: Mar 04, 2016 - Accepted: Aug 05, 2016

Citation: Kim M, Lee W-K, Kurz WA, Kwak D-A, Morken S, Smyth CE, Ryu D (2016). Estimating carbon dynamics in forest carbon pools under IPCC standards in South Korea using CBM-CFS3. iForest 10: 83-92. - doi: 10.3832/ifor2040-009 [online 2016-10-13]

Communicated by: Chris Eastaugh emissions between 2004 and 2013 (Pan et al. 2011). Concerns about global climate change have highlighted the importance of finding efficient ways to quantify forest carbon dynamics on regional, landscape, national and global scales (Kurz et al. 2013). Measurement of forest biomass provides an indication of $C$ sequestration in trees, as the amount of forest $C$ stock can be estimated from forest biomass, but additional information is required to estimate $C$ stocks in litter, dead wood and soil $C$ pools. There are two model-based approaches in quantifying forest $C$ dynamics: (i) empirical models, driven by field-based inventory data; and (ii) process-based models, driven by the simulation of photosynthesis (Kurz et al. 2009, Pilli et al. 2013). Process-based models, such as 3-PG (Landsberg \& Waring 1997), CENTURY (Metherall et al. 1994), and VISIT (Ito 2008), require extensive 
input datasets of vegetation, climate and soil variables, and fluxes which can be measured by eddy covariance flux towers. In South Korea, the data from flux towers are insufficient for informing process-based models. On the other hand, empirical models, such as EFISCEN (Nabuurs et al. 2000), CO2FIX (Nabuurs \& Schelhaas 2002), FORMICA (Böttcher et al. 2008), and CBMCFS3 (Kurz et al. 2009), are better suited than process-based models to utilize merchantable wood volume data collected from small scale investigations at plots in the field for or from large-scale surveys at the national level. The Korea Forest Service has conducted a National Forest Inventory (NFI) from 2005 over all South Korean forests (Korea Forest Research Institute 2011). This NFI contains sufficient information to estimate tree volume at the stand level. Therefore, for estimating the forest $\mathrm{C}$ dynamics in South Korea, it is more feasible to use an empirical model rather than a process-based model.

Most empirical forest $C$ dynamic models can only provide estimates starting from the reference year of the $\mathrm{NFI}$, and cannot consider uneven-aged stands or natural disturbances such as forest fires, insect outbreaks, and storms (Lindroth et al. 2009). However, the Carbon Budget Model for Canadian Forest Sector 3 (CBM-CFS3) can represent impacts of natural disturbances (Kurz et al. 2008), past and future carbon dynamics (Metsaranta et al. 2011), and uneven-aged stands (Pilli et al. 2013). Furthermore, the CBM-CFS3 implements Tier 3 approaches for estimating $C$ stocks and stock changes following the guidelines of the Intergovernmental Panel on Climate Change (IPCC) Good Practice Guidance (GPG) for the Land Use, Land-use Change, and Forestry (LULUCF - IPCC 2003) sector (Kurz et al. 2009). Reporting $C$ stocks and changes at the Tier 3 level may be required because it is anticipated that South Korea will have a future obligation to reduce greenhouse gas (GHG) emissions. In this study, we tested CBM-CFS3 for estimating past and future dynamics of forest carbon pools in South Korea as classified by the IPCC GPG and for supporting the establishment of a national-scale forest carbon budget in compliance with international reporting guidelines.

\section{Materials and methods}

\section{CBM-CFS3}

The Carbon Budget Model of Canadian Forest Sector (CBM-CFS3) is an inventorybased, yield-data driven model that simulates the stand- and landscape-level C dynamics of above- and belowground biomass, and dead organic matter (DOM) including soil (Kurz et al. 2009). The spatial framework conceptually follows the Reporting Method 1 (IPCC 2003), in which, for the purpose of estimating and reporting, the spatial units are defined by their geographic boundaries and all forest stands are geographically referenced to a spatial unit. Within a spatial unit, each forest stand is characterized by age, area, and up to 10 classifier types that provide administrative and ecological information, including species or forest type and link to appropriate yield curves, and parameters defining the silvicultural system. During the model run, a library of yield tables defines the gross merchantable volume production by age and class for each tree species and site index. These yield tables represent the volume in the absence of natural disturbances and management practices. The CBM applies the net annual increment (i.e., the periodic increment minus mortality from self-thinning) during the model run. Species-specific stand-level equations (Boudewyn et al. 2007) convert merchantable volume into aboveground biomass, partitioned into merchantable stemwood, other material (tops, branches, sub-merchantable size trees), and foliage components. The belowground biomass (coarse and fine roots), its increment, and annual turnover are calculated using the equations provided by Li et al. (2003). Annual dead wood and foliage input is estimated as percentages (i.e., turnover rates) applied to the standing biomass stock. To estimate the decomposition rate of each DOM pool, the CBM adjusts the base decomposition rates, defined at $10{ }^{\circ} \mathrm{C}$, by a temperature modifier based on the mean annual air temperature in each spatial unit and a pool-specific $Q^{10}$ value. DOM pools (dead wood, litter, and soil) are initialized using a procedure that considers site productivity (NPP), temperature-dependent decomposition rates, and disturbance history (Kurz et al. 2009). In the simulation of stand- and landscape-level carbon dynamics, the user can define natural and anthropogenic disturbances such as fire, insects, or storms, partial or clear-cut harvesting, or other disturbance types for which users define the impacts on C stocks (Kull et al. 2006). Users define the amount (area or C target), type, and intensity of each disturbance by the year and spatial unit (or groups of spatial units). Eligibility criteria, such as forest type, age, or other classifier values, can be used to define the eligible stands for each disturbance. Disturbance impacts are defined using a "disturbance matrix" that describes the proportion of $\mathrm{C}$ transferred between pools, transferred to the forest product sector, or released to the atmosphere for each disturbance type (Kurz et al. 2009). Post-disturbance dynamics can be specified in considerable detail, allowing for successional pathways and rates of regeneration. Afforestation and deforestation also can be represented as disturbance types with their own disturbance matrices and transitions to and from forestland. The model provides annual estimates of $C$ stocks and fluxes, such as annual $C$ transfers between pools, from pools to the atmosphere, and to the forest product sector. In this study, projections were limited to 2092 and the effects of possible environmental changes over 100 years have been excluded. CBM input data, including forest area by age class and yield tables, are described below.

\section{National Forest Inventory data}

$\mathrm{NFI}$ data were used to develop forest growth models for estimating present and future forest volumes by major tree species based on forest type and stand age. In South Korea, the $5^{\text {th }} \mathrm{NFI}$ was conducted for the entirety of South Korean forests from 2006 to 2010 (Korea Forest Research Institute 2011). The survey design consisted of systematic sampling at intervals of $4 \mathrm{~km}$ (longitude) $\times 4 \mathrm{~km}$ (latitude) across South Korea. Four circular sample plots were located at the intersection of each $4 \times 4 \mathrm{~km}$ grid line. Each sample plot (31.6 m radius) covered 0.16 ha. Forest characteristics (tree species, age, height, diameter at breast height - $d b h$, and number of trees) and topographical factors (coordinates, elevation, slope, and aspect) were measured at all sites (Korea Forest Service 2011).

The plot data were used to estimate $d b h$, tree height $(h)$, number of trees per hectare (Nha), and stand volume (Vha) using regression models developed by tree species.

\section{Yield tables}

The Korea Forest Service established stand yield tables for 10 major tree species, which provide information on tree volumes based on species, site index, and stand age (Korea Forest Service 2009). However, the Korean Map of Forests classifies the forest into 17 tree species, comprising more detail than is used in this study, which substitutes tree species recommended by the Korea Forest Service when certain species in the Forest Type Map (FTM) were not present in the yield tables. Moreover, there is no information on mixed forests in the stand yield index. According to NFI report (Korea Forest Research Institute 2011), most of mixed forests in South Korea were composed of red pine and Mongolian oak - the major species of coniferous trees and broadleaf in South Korea. Therefore, this research take into account that every mixed forest contains equal proportions of red pine and Mongolian oak. Consequently, $C$ dynamics of mixed forests were estimated using both coefficients of red pine and Mongolian oak in this study.

\section{Forest type map}

The $3^{\text {rd }}$ FTM was employed to predict the present forest volume. This map (scale 1:25.000) was produced from visual interpretation of aerial photographs and $\mathrm{NFI}$ data, and it outlined forest stands classified by tree species, $d b h$, age class, and canopy closure (Korea Forest Service 2000). Seventeen categories of tree species were specified. $d b h$ and age of stands were expressed as "dbh class" $(6-16 \mathrm{~cm}, 16-30 \mathrm{~cm}$, 


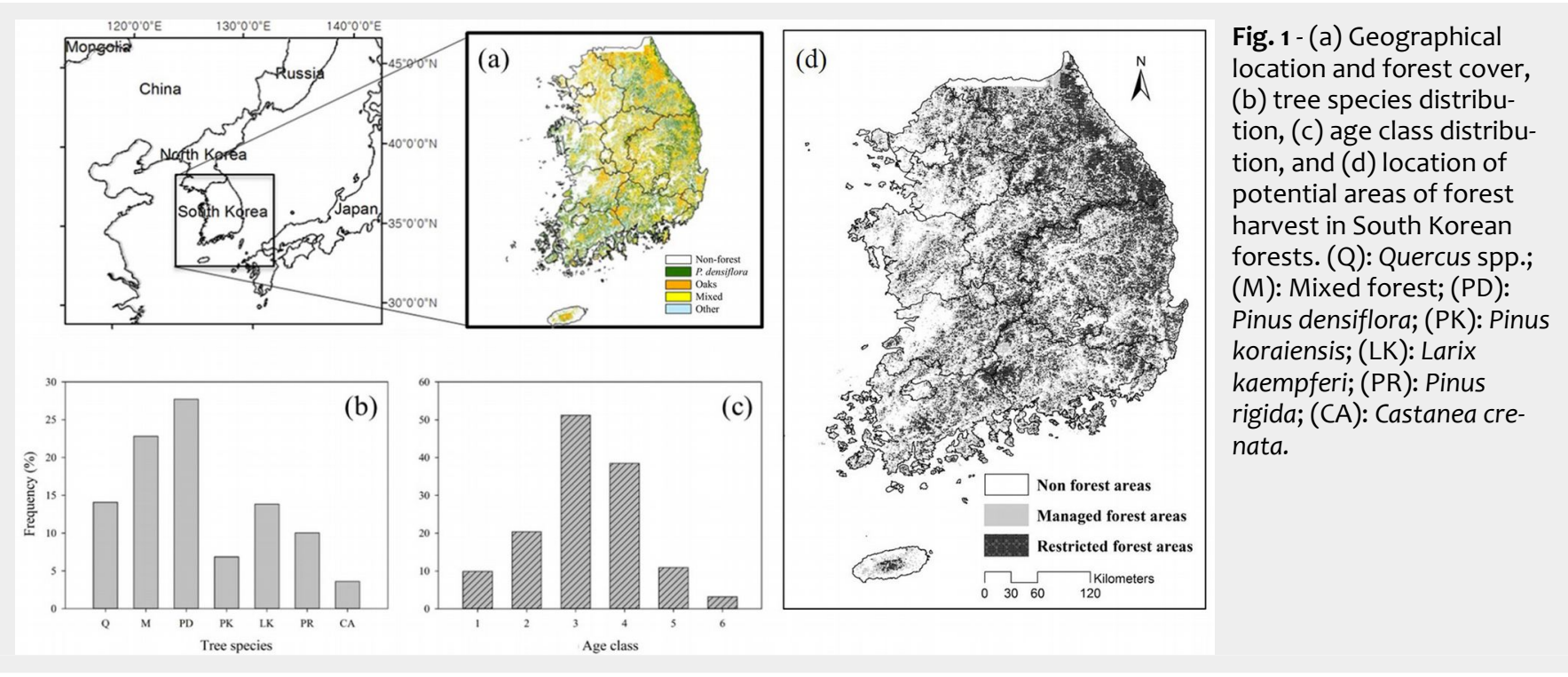

and over $30 \mathrm{~cm}$ ), and 10-year "age class". Canopy closure was classified into open, medium, and dense categories.

\section{Climate data}

The Korea Meteorological Administration (KMA) provided climate data, including monthly mean temperature, mean daily minimum temperature, and total precipitation, from 75 weather stations across South Korea from 1971 to 2000 . The data were interpolated with a $0.01^{\circ}$ grid size $(\approx 1$ $\mathrm{km}$ ) using Kriging and Inverse Distance Squared Weighting (IDW), considering the absolute temperature and precipitation lapse rate by elevation (Lull \& Ellison 1950). In this study, future climatic data were predicted under the $A 1 B$ scenarios from the IPCC Special Report on Emission Scenarios (IPCC 2000). These datasets were resampled into $0.01^{\circ}$ spatial resolution with the Geographic Coordinate System (GCS) and World Geodetic System 1984 (WGS 84).

\section{Study area}

The Korean peninsula is located in East Asia and shares oversea borders with China to the west and Japan to the east. The study area is contained within South Korea, and is located at $124^{\circ} 54^{\prime}-131^{\circ} 06^{\prime} \mathrm{E}$ and $33^{\circ}$ $09^{\prime}-38^{\circ} 45^{\prime} \mathrm{N}$ (Fig. 1a). Forest area covers about $63.7 \%(6,369,000 \mathrm{ha})$ of the total land area of South Korea, and evergreen forests (mainly Pinus densiflora), deciduous broad-leaved forests (mainly Quercus spp.), and mixed forests occupied approximately $40.5 \%, 27 \%$, and $29.3 \%$ of the total forest area in 2010, respectively (Korea Forest Service 2011 - Fig. 1b). These are the major tree species in South Korea, and they have important ecological, economical, and socio-cultural value (Kwak et al. 2012).

South Korea's once-rich forests were degraded in the $20^{\text {th }}$ century due to unmanaged logging for timber and fuel during the Japanese occupation (1910-1945) and the Korean War (1950-1953 - Tak et al. 2007). Since 1973, following periods of serious deforestation, the South Korean government has implemented the National Greening Program for the recovery of forests (Bae et al. 2012). After about 30 years of effort, South Korean forests have successfully recovered, and the stocking volume increased from $8.2 \mathrm{~m}^{3} \mathrm{ha}^{-1}$ in 1954 to 125.6 $\mathrm{m}^{3} \mathrm{ha}^{-1}$ in 2010 (Korea Forest Service 2011). Today, over $70 \%$ of South Korean forests are less than 40 years old (Fig. 1C).

\section{Overview of analytical process}

The overall process used in this study can be summarized as follows: (1) design of Spatial Units (SpUs) using various classifiers; (2) estimation of initial stand age and stand average dbh using NFI and FTM; (3) estimation of stand height, dominant tree height, site index, and stand volume based on stand age and stand average dbh using the Korean yield tables; (4) estimation of future changes of stand average $d b h$ and stand average height based on aging of stand; (5) estimation of forest volume in SpUs considering forest management; and (6) using the information in the previous five steps to estimate each forest carbon pool, defined by IPCC GPG, using the CBMCFS3 model.

\section{Preparation of inventory data on present forest status}

The CBM-CFS3 model input inventory is based on forest stand information. In previous research (Lee et al. 2014), plot-level data of the $5^{\text {th }} \mathrm{NFI}$ were converted to be representative for the entire forest area. The total forest area (6.34 M ha) in Korea was divided into 3890 stands. This approach has advantages: it reduces the data processing time and uses field survey data directly at the national level. However, extreme variation in stand characteristics of Korean forests was not captured, because the average size per stand was large (1600 ha). To overcome the limitations of previous studies, this study overlaid four layers (administrative district map, map sheet, FTM, and management type map - Tab. 1) to divide the forest of Korea into $1,134,800$ stands, which were on average 5.6 ha in size. Classifiers and stand age were assigned to each stand (Fig. 2). These stands were distributed within the 2250 spatial units recognized in this analysis.

No harvest activities were simulated in areas where forestry practices are restricted. These areas were identified using thematic maps such as FTM, forest site digital maps, and ecological zoning maps. Areas where forestry practices are restricted were defined as special forests (reserved forests, seed production forests, experimental forests, water conservation forests, natural reserve forests, landscape protection areas, and areas for protecting forest

Tab. 1 - Description of classifiers for running CBM-CFS3 in South Korean forests.

\begin{tabular}{|c|c|c|}
\hline Classifier & Summary & Data used \\
\hline Province & Administrative districts & $\begin{array}{l}\text { Administrative district map } \\
\text { of Korea }\end{array}$ \\
\hline Map sheet & 1:25.000 scale map sheets & Map index of Korea \\
\hline Forest type & $\begin{array}{l}\text { Definition of tree species for each } \\
\text { stand }\end{array}$ & $3^{\text {rd }}$ forest type map \\
\hline Age class & Definition of stand age for each stand & $3^{\text {rd }}$ forest type map \\
\hline DBH class & $\begin{array}{l}\text { Definition of average DBH for each } \\
\text { stand }\end{array}$ & $3^{\text {rd }}$ forest type map \\
\hline Management type & $\begin{array}{l}\text { Definition of restricted or manageable } \\
\text { forest }\end{array}$ & $\begin{array}{l}\text { Forest legislation and } \\
\text { geographical features }\end{array}$ \\
\hline
\end{tabular}




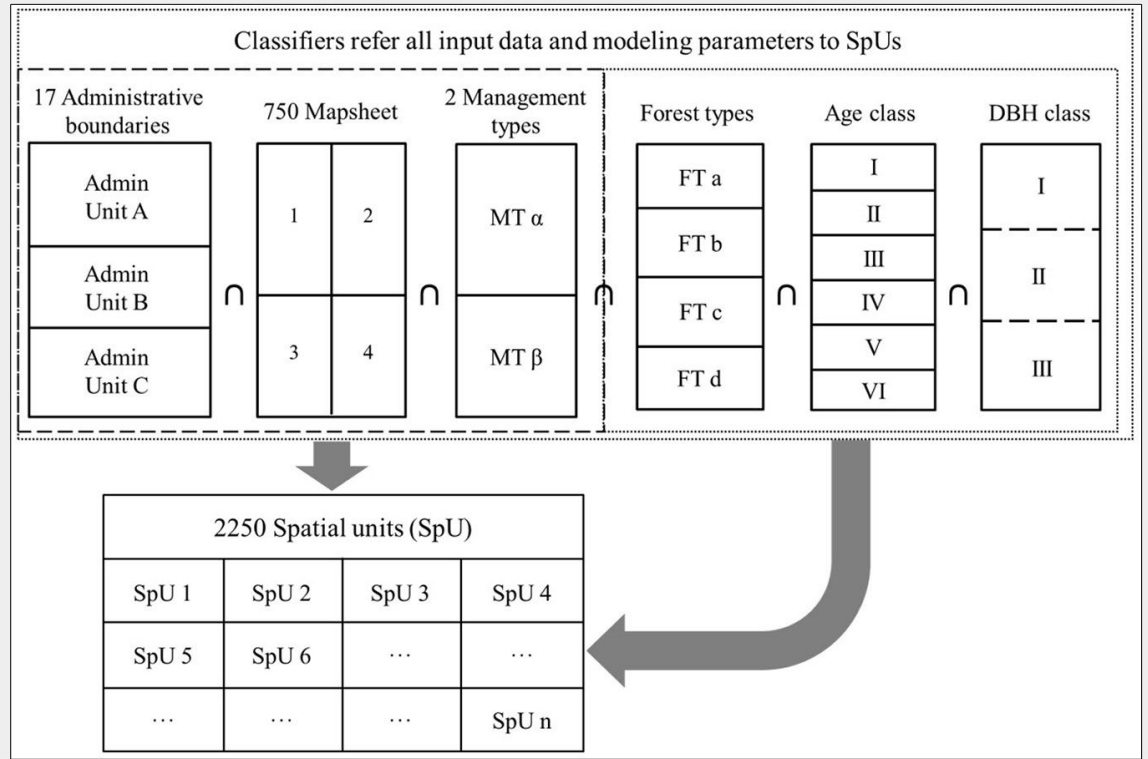

Fig. 2 - Schematic representation of the main input data required by CBM in order to define the Spatial Units (SpUs). The dashed line identifies the general classifiers and the dotted line delimits the information provided by the forest inventory, split between each SpU.

genetic resources) and management zones (green belt zones, national parks, wildlife sanctuaries, and protected areas including wetlands and cultural assets). In addition, impractical working conditions such as slopes of more than $25^{\circ}$, bedrock outcrops covering more than $30 \%$ of the surface, and mountain areas with altitudes of more than $900 \mathrm{~m}$ above sea level were categorized as restricted area.

The forest area with harvest activities, based on consideration of forest legislation and geographical conditions, occupied about $3,138,000$ ha, which is approximately $51.7 \%$ of the whole forest area $(6,067,400$ ha - Fig. 1d). The whole forest areas was included in the analyses of carbon dynamics. We considered that the forest area was constant in the analysis. Therefore, we do not include deforestation and afforestation (land-use changes) in this analysis.

\section{Volume estimation}

The Korean FTM contains information about species, age class, and dbh class. The FTM is classified into 17 species, $4 \mathrm{dbh}$ classes, and six 10-year age classes, but it is difficult to fully describe stand characteristics of each species using only this information. Therefore, in this research NFI data were used to subdivide the stand. NFI is based on 4000 permanent sample plots throughout forests of South Korea. These data from the NFI are considered highly reliable and can be used as model data for each forest type.

We sorted $d b h$ information for each species in each stand from the NFI data based on the information related to age class and dbh class obtained from the FTM. Moreover, we estimated the average $d b h$ of the stand of all species, based on each age class and $d b h$ class, matching the $d b h$ value of the corresponding age class and dbh class (Fig. 3 ). In addition, information on age class in FTM was derived and equated to match the stand age of each age class. To estimate average height, height of dominant trees, site index, and stand volume of each stand, we used the matched values of stand age and $d b h$ values to replace the information on dbh class and age class in the FTM (Fig. 3).

In general, the volume of an individual tree in a stand can be estimated by the tree height and $d b h$ (Segura \& Kanninen 2005 , Cutini et al. 2013). Moreover, the number of trees in one hectare (Nha) is essential to expand the volume of an individual tree to the total volume of a stand or forest. However, tree height and Nha information are not found in the FTM. To simulate the volume of stands in each $\mathrm{SpU}$, it is necessary to estimate the relationship between: (i) mean tree $d b h$ of stand ( $d b h)$ and mean tree height of stand (hm); (ii) hm and dominant tree height (ho); (iii) age, ho, and site index (SI); (iv) age, ho, and $d b h$; and (v) $\mathrm{dbh}, \mathrm{hm}$, and volume $(\mathrm{V})$. Considering relationships and growth characteristics, a growth model formula such as $h m=f(d b h)$ could be developed with NFI data and the optimal nonlinear regression forms (Tab. S1 in Supplementary Material). All basic forms of regression equations were obtained from Sit \& Poulin-Costello (1994). Four different types of regression forms were applied to estimate mean tree height for reflecting the growth characteristics of each tree species. Nonlinear regression analyses were performed for 12 tree species using SAS $^{\oplus}$ 9.1 (SAS Institute Inc. 2003) and NFI data. For this study, the regression forms with the highest accuracy were applied to each species (Tab. S2 in Supplementary Material). The every coefficients of growth model formula such as $h m=f(d b h)$ were significant at the relative lower 0.05 (Tab. S3 in Supplementary Material). Other regression equations and coefficients for $\mathrm{hm}$ $=f(h o), S I=f($ age,$h o), d b h_{i+1}=f\left(d b h_{i}, a g e_{i+1}\right.$, $\left.h o_{i+1}\right)$, and $V=f(d b h, h m)$ were applied to tree species developed by the Korea Forest Service (2009) (Tab. S1 in Supplementary Material).

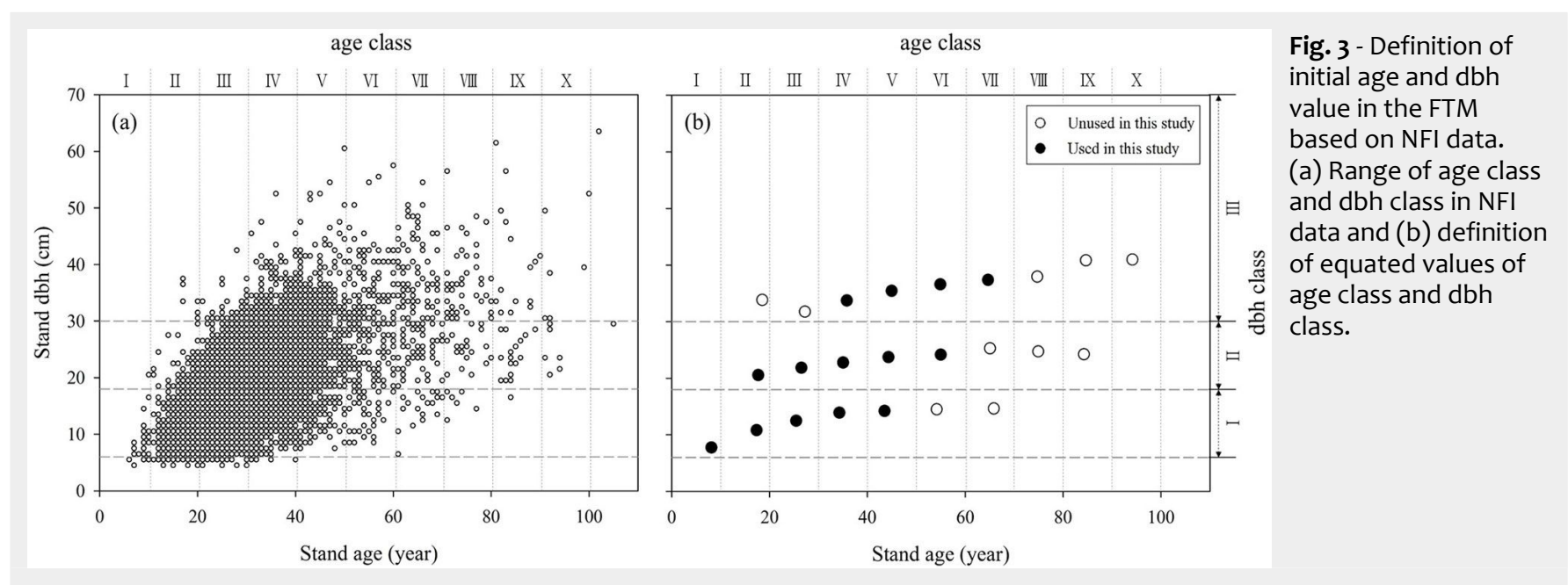


The $\mathrm{SI}$ is defined by the Korea Forest Service as the height of the dominant tree at 30 years of age. Therefore, to estimate the $\mathrm{SI}$ of each stand, a functional formula can be used (eqn. 1):

$$
S I=f(\text { ho, age })
$$

This research applied equations by either Chapman-Richards (Mitscherlich 1919) or Schumacher (1939) for each tree species to estimate the site index of stands (Tab. S4 in Supplementary Material). Coefficients proposed by the Korea Forest Service (2009) are shown Tab. S5 in Supplementary Material.

The future $d b h\left(d b h_{i+1}\right)$ was computed by adding one year to the present age (age ${ }_{i}$ ) of target tree species in the regression model. However, the direct application of age $e_{i+1}$ to the regression model forces all the $d b h_{i+1}$ to fit the regressed $d b h$ value corresponding to $a g e_{i+1}$ on the regression curve, even though $d b h_{i+1}$ can be estimated higher or lower than the regressed $d b h$ value according to the $d b h$ value of the previous year. Such forced fitting to the regression curve might lead to an underestimation in $d b h$ in $i+1$ years in sites with high Sl. On the other hand, poor sites (low SI) might lead to an overestimation of $d b h$ in $i+1$ years. To solve such fitting problems, the regression models of $d b h_{i+1}=f\left(d b h_{i}, a g e_{i+1}, S I\right)$ were transformed into the form of algebraic differences (see Tab. S1 in Supplementary Material - Bailey \& Clutter 1974, Jordan et al. 2006) and coefficients proposed by the Korea Forest Service (2009 - see Tab. S6 in Supplementary Material). Thereby, it is possible to estimate the future $d b h$ based on the current $d b h$ distribution of each stand.

As information about stand density is not included in the FTM, we used the following growth model (eqn. 2 ) to estimate the volume of stands. The coefficient of each tree species for eqn. 2 is derived from the Korea Forest Service (2009 - see Tab. S7 in Supplementary Material).

$$
V_{i}=a \cdot d b h_{i}^{b} \cdot h_{i}^{c}
$$

where $V$ is stand volume $\left(\mathrm{m}^{3} \mathrm{ha} \mathrm{a}^{-1}\right), d b h(\mathrm{~cm})$ is the tree average diameter, and $\mathrm{hm}(\mathrm{m})$ and $a, b, c$ are species-specific coefficients.

Dead organic matter (DOM) estimation As the volume or biomass of a living tree grows each year, some parts of the tree (such as fine roots, foliage, branches, etc.) are transferred to DOM carbon pools. This process is quantified by turnover rates that are specific to each biomass component in each ecozone of CBM-CFS3 (Kull et al. 2006). We used default turnover rates of Pacific Maritime ecozone in the CBM-CFS3 to estimate the amount of biomass that annually turns into DOM (Tab. 2).

The decay or decomposition rate of each DOM pool varies with temperature based on a pool-specific base decay rate (at 10
Tab. 2 - Biomass turnover and litterfall transfer rates (Kurz et al. 2009). (1): \% of

\begin{tabular}{|c|c|c|c|}
\hline CBM-CFS3 pool & $\begin{array}{l}\text { Turnover } \\
\text { rates } \\
\left.\text { (\% C yr } \text { yr }^{-1}\right)\end{array}$ & $\begin{array}{l}\text { DOM pool } \\
\text { receiving turnover }\end{array}$ & $\begin{array}{c}\text { Litterfall } \\
\text { transfer rate }\end{array}$ \\
\hline Merchantable stemwood (SW or HW) & 0.6 & Snag stems & 100 \\
\hline Other wood (SW or HW) & 4 & Snag branches AG fast & 2575 \\
\hline Foliage (SW) & 15 & AG very fast & 100 \\
\hline Foliage (HW) & 95 & $A G$ very fast & 100 \\
\hline Fine roots (SW or HW) & 64.1 & $A G$ very fast $B G$ very fast & 5050 \\
\hline Coarse roots (SW or HW) & 2 & AG fast $B G$ fast & 5050 \\
\hline
\end{tabular}
turnover transferred to each DOM pool.

$\left.{ }^{\circ} \mathrm{C}\right)$, Q10 value, and scaling factor that can adjust decay rates based on the degree of canopy closure (not used in this study Kurz et al. 2009). Therefore, for application of the CBM to Korea, average air temperature data are required for each spatial unit. This study used the default decay parameters (Kurz et al. 2009), but with temperature data for Korea.

\section{Application of thinning and cutting schedule}

Under the sustainable forest management law established by the Korea Forest Service, Korean forest cover needs to be thinned out by $25 \%$ at stand age 25 years. Therefore, this study reflected this legal requirement. Furthermore, a clear cut harvest at the final age of maturity for each tree species is implemented. These management activities affect the future carbon budget of the forests of South Korea. The simulations in this study did not include any natural disturbances and changes in landuse such as afforestation or deforestation.

\section{Model validation}

In this study, the carbon budget of the five carbon pools defined in the IPCC GPG in South Korean forests from 1992-2092 was estimated by applying the CBM-CFS3 model and validated using the $5^{\text {th }} \mathrm{NFI}$, statistical data, and other research. For biomass, we compared model values to those of the statistical yearbook of forestry in South Korea between 1992 and 2010 and estimated $R^{2}$ and RSME to indirectly validate the estimated biomass $C$ stocks. For soil and litter $C, 5^{\text {th }} \mathrm{NFI}$ data were used to validate the estimates. Estimates of soil and litter $\mathrm{C}$ were not included in earlier NFI versions.

\section{Results and discussion}

\section{Aboveground and belowground} biomass

Changes in the $C$ stock density of Total Aboveground Biomass (TAB) between 1992-2092 are depicted in Fig. 4a. Typically, the amounts of $C$ stocks of TAB show a pattern of increase or decrease due to growth and thinning and cutting activities (thinning every 25 years and cutting by final maturity age - Fig. $4 a$ ). The $C$ stocks of TAB showed rapid growth rates until 2034, fol- lowed by variations in $\mathrm{C}$ density that reflect forest management activities to 2050, and stable densities after 2050. The C stock density of TAB in South Korean forests increased from $8.86 \mathrm{Mg} \mathrm{C} \mathrm{ha-1}$ in 1992 to $73.96 \mathrm{Mg} \mathrm{C} \mathrm{ha}^{-1}$ in 2034 (Fig. 4a). Averaged over the period 1992-2034, the annual increase in C density of TAB was $1.55 \mathrm{Mg} C$ $\mathrm{ha}^{-1} \mathrm{yr}^{-1}$.

The projected $C$ stocks of TAB decreased drastically from $73.96 \mathrm{Mg} \mathrm{C} \mathrm{ha}^{-1}$ in 2034 to $56.46 \mathrm{Mg} \mathrm{C} \mathrm{ha}^{-1}$ in 2045 due to forest management activities. Following the management instructions of the Korea Forest Service, many forests will reach a final cutting and reforestation age in 2040, which results in the decrease of TAB at that time. This decline is caused by the imbalanced age structure of Korean forests; in 2009, about $67 \%$ of forests in Korea was between 30 and 40 years old (Korea Forest Service 2011) and thus will require that large areas are cut and replanted in 2040, as provided by the forest management practice guide in Korea.

The $C$ stock density of TAB slowly increased thereafter from $56.46 \mathrm{Mg} \mathrm{C} \mathrm{ha}^{-1}$ in 2045 to $68.55 \mathrm{Mg} \mathrm{C}^{-1}$ in 2092. Averaged over the 2045-2092 period, the annual increase in C density of TAB was $0.25 \mathrm{Mg} C$ $\mathrm{ha}^{-1} \mathrm{yr}^{-1}$. This reflects the decreased growth rates of the aging forests of South Korea and the increasing amount of biomass carbon removed through thinning and final clear cutting.

This increasing and decreasing pattern of the $C$ stocks of TAB reflects the impacts of thinning and final cutting practices as well as forest regrowth (Fig. 4a). Thinning and cutting can reduce the amount of aboveground biomass but enhance the forest growth rate. Over the period 1992 to 2092, thinning and cutting transfer a cumulative $206 \mathrm{Tg} C$ from forests to meet society's demands for timber, fiber and energy (Fig. 4c). The $C$ stock of foliage is relatively low compared to other aboveground $C$ pools, but it also shows a small increase.

The $C$ stock density of Total Belowground Biomass (TBB) follows the pattern of TAB (Fig. 4b), because TAB and TBB are closely related and $C$ stocks of live coarse roots are also affected by the thinning and cutting schedule. The $C$ stock of fine roots shows a relatively small increase similar to foliage. The $C$ stock of belowground bio- 

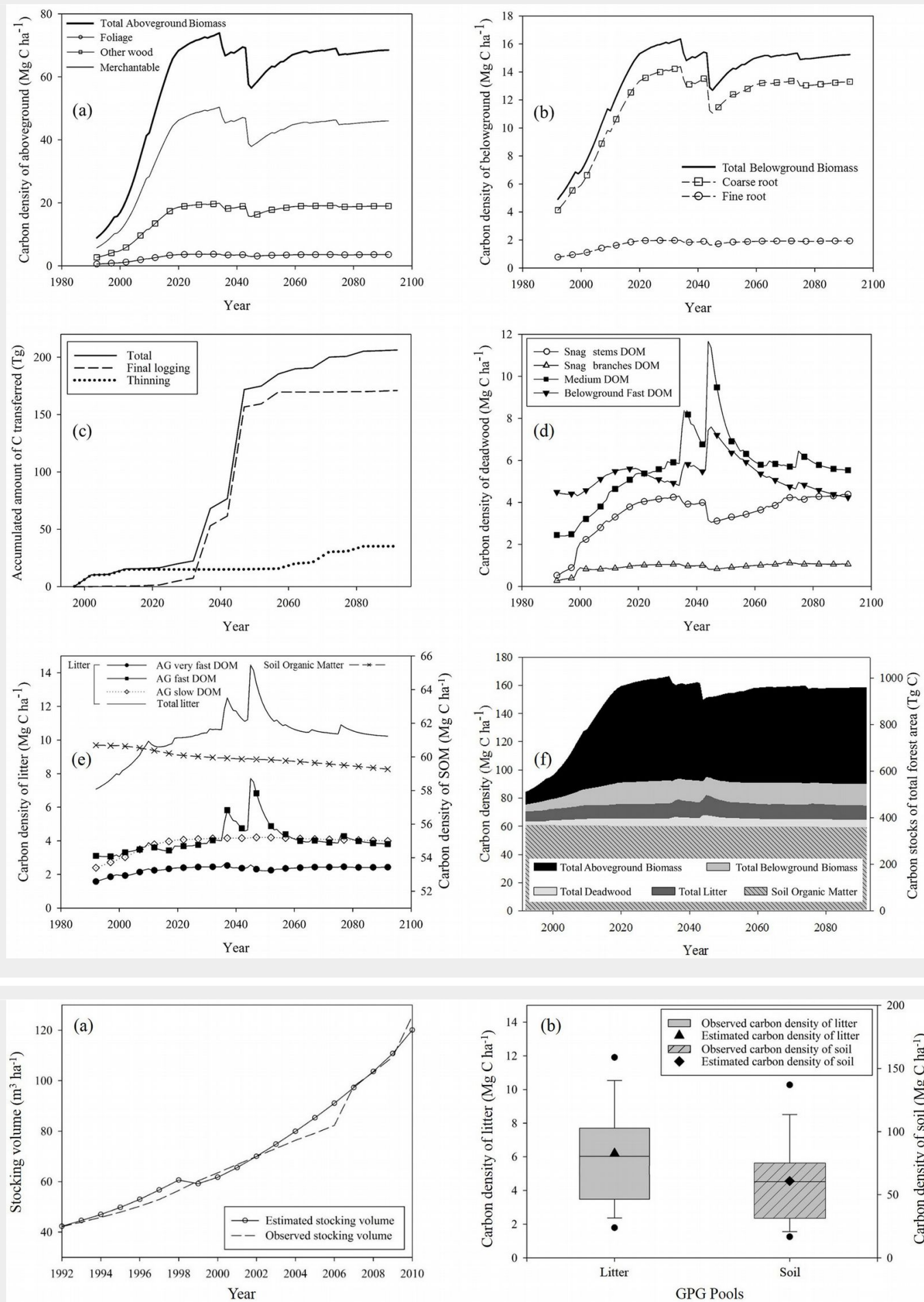

Fig. 5 - (a) The time series of the estimated and observed (statistical data) stocking volume in South Korean forests during 1992 2010. The observed stocking volumes for each year were compiled from those published by the Korea

Forest Service in the Statistical Yearbook of Forestry. (b) Comparison between the estimated and observed carbon (C) densities of litter and soil. For each box plot, top circle is $95^{\text {th }}$ percentile, lower circle is $5^{\text {th }}$ percentile, top bar is $90^{\text {th }}$ percentile, lower bar is $10^{\text {th }}$ percentile, top of box is upper or third quartile, bottom of box is lower or first quartile, middle bar is median value. (c) Annual damaged area and volume from natural and artificial

disturbances (Korea Forest Service 2011). (d) Annual forest pests and diseases outbreaks and controlled area (Korea Forest Service 2011). (Fire): burned forest area from forest fires; (Insects): clear cut area affected from pest damage by Korea Forest Service; (Illegal activities): area affected by illegal logging activities. 
mass was analyzed to be about $23-27 \%$ of the $C$ stock of aboveground biomass.

\section{Dead wood}

Changes in C stock density of dead wood are also affected by forest management activities (Fig. 4d). Within the four types of dead wood, medium DOM and belowground fast DOM (which includes dead coarse roots) tend to increase in the presence of forest management activities (Fig. 4d). Compared with the TAB and TBB C stocks, the $C$ stock of medium DOM and belowground fast DOM showed an opposite pattern. Forest management activities include cutting standing trees, which decreases the $C$ stock of total above- and belowground biomass, but increases the $C$ stocks of DOM because the transfer of $C$ to woody debris and dead roots adds more $C$ than the loss from these pools during forest management activities. This effect is projected to be particularly significant in 2044 , when the $C$ stock of TAB will be reduced by about $11.6 \mathrm{MgC} \mathrm{ha} \mathrm{Mr}^{-1}$ (from 69.2 $\mathrm{MgC} \mathrm{ha}^{-1}$ to $57.6 \mathrm{Mg} \mathrm{C} \mathrm{ha}^{-1},-16.7 \%$ ), while the $C$ stock of medium DOM and belowground fast DOM will increase by about $4.8 \mathrm{Mg} \mathrm{C}$ ha $^{-1} \mathrm{yr}^{-1}$ (from 6.9 Mg C hato $11.7 \mathrm{MgC} \mathrm{ha}^{-1},+69.8 \%$ ) and $1.9 \mathrm{MgC} \mathrm{ha}^{-1}$ $\mathrm{yr}^{-1}$ (from $5.5 \mathrm{MgC} \mathrm{ha}^{-1}$ to $7.4 \mathrm{MgC} \mathrm{ha}^{-1}$, $+34.7 \%$ ), respectively (Fig. $4 \mathrm{~d}$ ).

However, snag stems DOM and snag branches DOM, which mainly occur naturally from dead trees, show a decreasing tendency in the 2045, because the clear cut disturbance matrix in CBM-CFS3 represents cutting of the snags which transfers $C$ to the medium pool (Fig. 4d). The $C$ stock density of snag stems DOM and snag branches DOM will decrease from $4.0 \mathrm{Mg} \mathrm{C}$ $\mathrm{ha}^{-1}$ to $3.2 \mathrm{MgC} \mathrm{ha}^{-1}$ and $1.0 \mathrm{MgC} \mathrm{ha}^{-1}$ to 0.8 $\mathrm{MgC} \mathrm{ha-1}$, respectively, in 2045.

\section{Litter}

Similar to $C$ stock changes in dead wood, the $C$ stock change in total litter was primarily linked to changes in forest management activities, because of the relatively high amount of residue transferred to DOM during thinning and cutting activities.

Within the three types of litter, aboveground fast DOM tends to increase with forest management activities (Fig. 4e). The C stock density of aboveground fast DOM increases from 4.6 Mg C ha' to $7.7 \mathrm{Mg} \mathrm{C}^{-1} \mathrm{ha}^{-1}$ in 2045. However, aboveground very fast DOM and aboveground slow DOM gradually increase from 1.6 and $2.4 \mathrm{Mg} \mathrm{C} \mathrm{ha}^{-1}$ in 1992 to 2.4 and $4.0 \mathrm{Mg} \mathrm{C} \mathrm{ha}^{-1}$ in 2092, respectively, with almost no effect from forest management activities. The $C$ stock density of total litter slowly increases from $7.1 \mathrm{Mg} \mathrm{C} \mathrm{ha-1}$ in 1992 to $11.2 \mathrm{Mg} \mathrm{C} \mathrm{ha}^{-1}$ in 2034. In the years of extensive forest management activities the simulation results estimated two peaks, which reached 12.5 $\mathrm{Mg} \mathrm{C} \mathrm{ha-1}$ in 2037 and $14.4 \mathrm{Mg} \mathrm{C} \mathrm{ha}^{-1}$ in 2045. However, the $C$ stocks of total litter start to gradually decrease and stabilize during 2046-2092.
Tab. 3 - Comparison of living biomass carbon (C) density and NEP of South Korean forests with those of previous studies.

\begin{tabular}{lclcl}
\hline Category & $\begin{array}{l}\text { Year or } \\
\text { period }\end{array}$ & Model & Estimate & Reference \\
\hline & \multirow{2}{*}{2001} & Statistical model & 34.4 & Choi \& Chang (2004) \\
& KFSC & 39.7 & Lee et al. (2014) \\
Mean C density & & CBM-CFS3 & 34.1 & This study \\
$\left(\right.$ Mg C ha $\left.^{-1}\right)$ & \multirow{2}{*}{2010} & Statistical model & 72.9 & Nam et al. (2015) \\
& & CBM-CFS3 & 68.0 & This study \\
\hline
\end{tabular}

\section{Soil organic matter}

Soil organic matter density shows a very small decrease from about $60.7 \mathrm{Mg} \mathrm{C}^{-1}$ to $59.3 \mathrm{Mg} \mathrm{C} \mathrm{ha}^{-1}$ (Fig. 4e). This changing pattern of soil organic matter $C$ stocks could be partially explained by future climate data used as input data, as future air temperature is predicted to increase under the $\mathrm{A} 1 \mathrm{~B}$ scenario and the decomposition rates in the model increases with temperature (Kurz et al. 2009).

\section{Total carbon stock}

Simulation results showed that the carbon stocks of total forested areas nearly double from 509.7 to $1007.3 \mathrm{Tg} C$ at a rate of $11.8 \mathrm{Tg} \mathrm{C} \mathrm{yr}^{-1}\left(1.96 \mathrm{Mg} \mathrm{ha}^{-1} \mathrm{yr}^{-1}\right)$ during the period 1992-2034, but then stabilize as the annual increment of carbon storage decreases (Fig. 4f). There are three causes for the decrease. First, the annual increment of carbon density declines as the $48.3 \%$ of reserved forests in Korea increase in average age, because they are not subject to forest management. Second, increasing biomass removals on managed forests through thinning and clear cutting decreases $C$ density, and third, rising temperatures caused by climate change represented in the model result in greater annual losses of dead organic matter and soil organic horizon carbon through increased heterotrophic respiration in later decades. Temperature in general has an effect on soil respiration and the decay rates of dead organic matter $\mathrm{C}$ pools (Peltoniemi et al. 2009).

\section{Results validation}

The estimated stocking volumes simulated by the CBM-CFS3 model were compared with the observed stemwood volume data to indirectly validate the estimated biomass $C$ stocks. The time sequence of estimated stocking volumes showed a trend similar to that of observed stocking volumes on a national scale $\left(R^{2}=\right.$ 0.93 , RMSE = $3.44-$ Fig. 5a). According to the Statistical Yearbook of Forestry from NFI (Korea Forest Service 2011), the stocking volume in South Korean forests increased from 42.1 to $125.6 \mathrm{~m}^{3} \mathrm{ha}^{-1}$ between 1992 and 2010. The simulation result showed that it increased from 42.3 to 120.0 $\mathrm{m}^{3}$ ha $\mathrm{A}^{-1}$ during that period. As the results were similar, it could be inferred that the model successfully reflected the volume trends of Korean forests, which further suggests successful reconstruction of age distribution at the national scale, while uncertainties remain for individual stands.

A comparison of model estimates and $\mathrm{NFI}$ inventory measurements for litter and soil C stocks showed partial agreement (Fig. 5b). According to NFI, mean carbon density of litter and soil in Korean forests were 6.03 (SD: 3.36) and 60.06 (SD: 44.69) Mg C $\mathrm{ha}^{-1}$, respectively. Estimated values obtained from the CBM-CFS3 model in 2010 were 6.19 and $60.46 \mathrm{Mg} \mathrm{C} \mathrm{ha-1.}$

Soil type could affect the decay rate of humus, and ultimately the dead organic matter $C$ dynamics. Even though this research did not consider soil type, the outcome was similar to actual amounts of soil carbon. There were two possible explanations for these results. First, the spatial scale of forests in Korea is not too large to show differences between forest areas, and soil type does not vary by region. Research by Lee et al. (2014) used the Korean Forest Soil Carbon (KFSC) model to estimate the carbon amount of DOM and compared the outcome with NFI data, which proved to be highly accurate except for the Jeju province, even though the research did not consider soil type. The Jeju province is a volcanic island located far from the mainland, and its soil differs greatly from soils on the mainland (Ahn \& Chon 2010).

In fact, most research on quantifying litter and soil carbon conducted in Korea has not considered soil type, and it has been proven that carbon stocks mainly differ not because of soil but because of forest type and age class. In addition, forest types are affected by soil types (Webb 1968). Each forest type requires different soil types; therefore, forest type data input into CBMCFS3 could partially reflect the differences in soil types which can affect forest productivity.

We compared the living forest biomass ( $A G B$ and $B G B$ ), which have been compared in this study to previous research results from South Korean forests (Tab. 3). First, living biomass estimates of CBM-CFS3 showed a very similar pattern, but were slightly smaller than previous research (Choi \& Chang 2004, Lee et al. 2014, Nam et al. 2015). Previous reports did not consider forest management under the Korea Forest Service law, but our research included a certain amount of timber harvest. Therefore, this study, as distinguished from the previous research that used a process- 
based model, successfully reflected the changes in annual growing stock (Tab. 3).

Second, the changing trend of $C$ stocks of $T A B$ with forest management showed a similar trend as previous research. Nam et al. (2015) analyzed the changes of carbon storage considering actual and potential forest cover, and the final cutting age in South Korea from 2010-2100 in 10-year periods. In their study, a decrease in the C stock of aboveground biomass in South Korean forests was also found to range from 74.8 Mg C ha-1 in 2040 to $35.3 \mathrm{Mg} \mathrm{C}$ ha $^{-1}$ in 2060, because most forests are anticipated to reach a final cutting age between 2040 and 2060 and, hence, will be cut. Nam et al. (2015) assumed that forest management applies to an entire forest and estimated the changes of $C$ stock in 10year periods, so the result of the research differs slightly from ours, but the studies show similarities in the trend of changes in C stock.

\section{Volume change through thinning and cutting schedule}

According to the regulations of the Korea Forest Service, when the stand of any tree species reaches 25 years of age a thinning activity removing around $25 \%$ of its total stand volume should be undertaken. In addition, every tree species has its own final cutting age. In this analysis, therefore, every tree species was thinned by $25 \%$ of the total stand volume when the stand age reached 25 years. The thinning happens only once per stand, hence, thinned stands grow continuously until their cutting age and then regenerate to the same tree species. This process was repeated during the 100 years of the CBM-CFS3 simulation. Because most of the mountainous area in South Korea was afforested after the 1970s, a decrease in forest volume by thinning appeared during mid-to-late 1990 s when many stands reached 25 years of age. In addition, a large decrease in volume is projected from early 2030 to mid 2040 (Fig. 4f), as most species have a final cutting age of 60 to 70 years.

\section{Management implications for supply of} carbon to Korean society

The rate of carbon transfer from Korea's forests to Korean society has changed over time. At the start of the simulation most stands are too young for the final cutting. The amount of carbon transferred out of the forest through thinning and clear felling increases over time and is highly variable (Fig. 4C). The cumulative amount of carbon removed from Korea's forests between 1992 and 2092 is 206.3 Tg C. This is carbon removed from the atmosphere and is available to meet Korea's needs for timber, fiber and energy. Note that despite these transfers of carbon to harvested wood products and bioenergy, ecosystem carbon stocks increased between 1992 and 2092. Sustainable forest management and the continuous supply of timber, fiber and energy can help contribute to climate change mitigation objectives in Korea. Some of the carbon removed from forests will be transferred to long-lived wood products and will continue to store carbon for many years to come. Moreover, some of the long-lived wood products can displace other emissions-intensive products such as concrete, steel or plastics and further contribute to climate change mitigation objectives (Lemprière et al. 2013).

\section{Uncertainties}

Although we estimated $C$ stock values and levels of change within South Korean forests, including biomass and dead organic matter, uncertainties remain. In this study, each $C$ stock values were estimated using carbon emission factors proposed by the Korea Forest Research Institute (2014). According to this report, the average uncertainties of basic wood density, biomass expansion factor, root-shoot ratio were estimated $3.6,7.0$ and $14.9 \%$. These factors to be used are usually species specific (Levy et al. 2004), however, they may also depend on site (Wirth et al. 2004), tree size and age (IPCC 2003, Levy et al. 2004), because these all affect the biomass allocation strategies of the trees. However, we considered that each carbon emission factors were hold value. Our results involved these uncertainties.

In addition, this research did not consider the natural (disease and insect pests, wind damage, landslide) and anthropogenic (forest fires, illegal activities, land cover change) disturbances that occur every year. The forests in Korea suffered an average loss of $152,900 \mathrm{~m}^{3} \mathrm{yr}^{-1}$ of stand volume in an average area of $2561 \mathrm{ha} \mathrm{yr}^{-1}$ in a recent 10 year-span (2001-2010) due to forest fires, logging to address disease and insect pests, and illegal activities (Korea Forest Service 2011 - Fig. 5C). In other words, 0.4\% of the total area of forest in Korea is affected by disturbances every year. Furthermore, during the same period, $307.2 \mathrm{~K}$ ha $\mathrm{yr}^{-1}$ of forest has been stricken by diseases and pests (Fig. 5d). While most areas (69.6\% - Korea Forest Service 2011) experiencing diseases and pests are treated to prevent the breeding of pests or to encourage their extermination, the ecosystem and carbon cycle within these areas is still affected. To enable a more precise and comprehensive assessment of South Korean forest $C$ cycles, some important influences on $\mathrm{C}$ balance need to be considered, such as atmospheric $\mathrm{CO}_{2}$ fertilization (Bellassen et al. 2011), $\mathrm{N}$ deposition (Fischer et al. 2011), leaching (Luyssaert et al. 2010), forest area changes (Liski et al. 2006), forest cover changes (Choi et al. 2011), forest growth changes (Byun et al. 2013), illegal activities, and other disturbances (Kurz et al. 2008, Oubrahim et al. 2015).

\section{Conclusions}

In this study, the five carbon pools defined in the IPCC GPG in South Korean forests and their changes from 1992-2092 were estimated through the application of the CBM-CFS3 model using Korean NFI and other forest and climate data. Simulation results showed that the carbon stocks of the total forest area increased from 509.7 to $1007.3 \mathrm{Tg} \mathrm{C}$ at a rate of $11.8 \mathrm{Tg} \mathrm{C} \mathrm{yr}^{-1}$ during the period 1992-2034. However, forest carbon stocks were projected to decrease due to the thinning and end-of-rotation harvest, as most forested areas will reach the specified cutting age between 20352050. Among the four types of dead wood, medium DOM and belowground fast DOM tend to increase with the implementation of forest management practices. This results from the increase of woody debris and dead roots that are left behind after forest management activities, and demonstrates the carbon dynamics within ecosystem pools as affected by forest management. The forest carbon stocks were estimated to gradually increase from 20502090 with a low growth rate, because the growth rate of forests classified as restricted area not subject to forest management (approximately $47 \%$ of the total forest) decreases as stands age. The carbon dynamics within ecosystem pools according to climate change and forest management were also predicted. Through harvesting, over the 100 year period more than $200 \mathrm{Tg} C$ were transferred from South Korea's forests to meet demands for timber, fiber and energy. A small gradual decrease in soil carbon stocks was predicted, as a temperature increase (according to the climate change scenario applied in this study) enhanced decomposition rates. The results of this study can support the establishment of a national-scale forest carbon budget compliant with international reporting guidelines.

\section{Acknowledgements}

This study is supported by the Korea Ministry of Environment under the "Climate Change Correspondence Program" (Project Number: 2014001310008). We appreciate the cooperation of the staffs who worked on data collection in Korea Forest Inventory Center, National Forestry Cooperative Federation. This work was also conducted under the Memorandum on Research Collaboration between the Korea Forest Service and the Canadian Forest Service. We also thank Jongyeol Lee for technical support.

\section{References}

Ahn JS, Chon CM (2010). Geochemical distributions of heavy metals and $\mathrm{Cr}$ behavior in natural and cultivated soils of volcanic Jeju island, Korea. Geosystem Engineering 13: 9-20. - doi: 10.1080/12269328.2010.10541304

Bae JS, Joo RW, Kim YS (2012). Forest transition in South Korea: reality, path and drivers. Land Use Policy 29: 198-207. - doi: 10.1016/j.landuse pol.2011.06.007

Bailey RL, Clutter JL (1974). Base-age invariant polymorphic site curves. Forest Science 20: 155- 
159. [online] URL: http://www.ingentaconnect. com/content/saf/fs/1974/00000020/00000002/ artoo013

Bellassen V, Viovy N, Luyssaert S, Le Maire G, Schelhaas MJ, Ciais P (2011). Reconstruction and attribution of the carbon sink of European forests between 1950 and 2000. Global Change Biology 17: 3274-3292. - doi: 10.1111/j.1365-2486. 2011.02476.x

Böttcher H, Freibauer A, Obersteiner M, Schulze ED (2008). Uncertainty analysis of climate change mitigation options in the forestry sector using a generic carbon budget model. Ecological Modelling 213 (1): 45-62. - doi: 10.1016/j. ecolmodel.2007.11.007

Boudewyn P, Song X, Magnussen S, Gillis MD (2007). Model-based, volume-to-biomass conversion for forested and vegetated land in Canada. Canadian Forest Service, Victoria, Canada, pp. 111. [online] URL: http://sbisrvnt web.uqac.ca/archivage/030078750.pdf

Byun JG, Lee WK, Kim M, Kwak DA, Kwak H, Park T, Byun WH, Son Y, Choi JK, Lee YJ, Saborowski J, Chung DJ, Jung JH (2013). Radial growth response of Pinus densiflora and Quercus spp. to topographic and climatic factors in South Korea. Journal of Plant Ecology 6 (5): 380-392. doi: 10.1093/jpe/rttoo1

Choi SD, Chang YS (2004). Factors affecting the distribution of the rate of carbon uptake by forests in South Korea. Environmental Science and Technology 38: 484-488. - doi: 10.1021/es $034533 \mathrm{u}$

Choi S, Lee WK, Kwak DA, Lee S, Son Y, Lim JH, Saborowski J (2011). Predicting forest cover changes in future climate using hydrological and thermal indices in South Korea. Climate Research 49: 229-245. - doi: 10.3354/cro1026

Cutini A, Chianucci F, Manetti MC (2013). Allometric relationships for volume and biomass for stone pine (Pinus pinea L.) in Italian coastal stands. iForest 6: 331-337. - doi: 10.3832/ifor 0941-006

Fischer R, Aas W, De Vries W, Clarke N, Cudlin P, Leaver D, Lundin L, Matteucci G, Matyssek R, Mikkelsen TN, Mirtl M, Oztürk Y, Papale D, Potocic N, Simpson D, Tuovinen J-P, Vesala T, Wieser G, Paoletti E (2011). Towards a transnational system of supersites for forest monitoring and research in Europe - an overview on present state and future recommendations. iForest 4: 167-171. - doi: 10.3832/ifor0584-004 IPCC (2003). Good practice guidance for land use, land-use change and forestry. Institute for Global Environmental Strategies (IGES), Hayama, Japan, pp. 675. [online] URL: http://www. ipcc-nggip.iges.or.jp/

IPCC (2000). Special report on emissions scenarios. Cambridge University Press, Cambridge, UK, pp. 881. [online] URL: http://www.ipcc. ch/pdf/special-reports/emissions_scenarios.pdf Ito $A$ (2008). The regional carbon budget of East Asia simulated with a terrestrial ecosystem model and validated using AsiaFlux data. Agricultural and Forest Meteorology 148: 738-747. doi: 10.1016/j.agrformet.2007.12.007

Jordan L, Souter R, Parresol B, Daniels RF (2006). Application of the algebraic difference approach for developing self-referencing specific gravity and biomass equations. Forest Science 52: 81-92. [online] URL: http://www. srs.fs.usda.gov/pubs/ja/ja_jordano01.pdf Korea Forest Research Institute (2011). The $5^{\text {th }}$ national forest inventory report. Korea Forest Research Institute, Seoul, Rep. of Korea, pp. 166. [online] URL: http://book.nifos.go.kr/KFRI CAB/IMG/006/002/157739.pdf

Korea Forest Service (2000). Forest and forestry technique. Korea Forest Service, Daejeon, Rep. of Korea, pp. 513. [online] URL: http://book. nifos.go.kr/KFRICAB/IMG/006/005/153098.pdf Korea Forest Service (2009). Table of tree volume/mass and yield table. Korea Forest Service, Daejeon, Rep. of Korea, pp. 261. [online] URL: http://book.nifos.go.kr/KFRICAB/IMG/006/ 001/154930.pdf

Korea Forest Service (2011). Statistical Yearbook of Forestry 2011. Korea Forest Service, Daejeon, Rep. of Korea, pp. 41. [online] URL: http:// ibook.forest.go.kr/Viewer/4CSZIWFX2DKT Korea Forest Research Institute (2014). Carbon emission factors and biomass allometric equations by species in Korea. Korea Forest Research Institute, Seoul, Rep. of Korea, pp. 97. [online] URL: http://www.forest.go.kr/newkfs web/cop/bbs/selectBoardArticle.do?nttld=3052 798\&bbsld=BBSMSTR_1492\&mn=KFS_02_10_1 3_20

Kull SJ, Kurz WA, Rampley GJ, Banfield GE, Schivatcheva RK, Apps MJ (2006). Operationalscale carbon budget model off the Canadian forest sector (CBM-CFS3) Version 1.0: user's guide. Natural Resources Canada, Canadian Forest Service, Edmonton, Canada, pp. 319. [online] URL: http://cfs.nrcan.gc.ca/pubware house/pdfs/26683.pdf

Kurz WA, Stinson G, Rampley GJ, Dymond CC, Neilson ET (2008). Risk of natural disturbances makes future contribution of Canada's forests to the global carbon cycle highly uncertain. Proceedings of the National Academy of Sciences USA 105: 1551-1555. - doi: 10.1073/pnas.07 08133105

Kurz WA, Dymond CC, White TM, Stinson G, Shaw CH, Rampley GJ, Smyth C, Simpson BN, Neilson ET, Trofymow JA, Metsaranta J, Apps MJ (2009). CBM-CFS3: a model of carbon-dynamics in forestry and land-use change implementing IPCC standards. Ecological Modelling 220: 480-504. - doi: 10.1016/j.ecolmodel.2008. 10.018

Kurz WA, Shaw $\mathrm{CH}$, Boisvenue $\mathrm{C}$, Stinson $\mathrm{G}$, Metsaranta J, Leckie D, Dyk A, Smyth C, Neilson ET (2013). Carbon in Canada's boreal forest - A synthesis. Environmental Reviews 21: 260-292. doi: 10.1139/er-2013-0041

Kwak DA, Lee WK, Son Y, Choi S, Yoo S, Chung DJ, Lee SH, Kim SH, Choi JK, Lee YJ, Byun WH (2012). Predicting distributional change of forest cover and volume in future climate of South Korea. Forest Science and Technology 8: 105115. - doi: 10.1080/21580103.2012.673751

Landsberg JJ, Waring RH (1997). A generalized model of forest productivity using simplified concepts of radiation-use efficiency, carbon balance and partitioning. Forest Ecology and Management 95 (3): 209-228. - doi: 10.1016/S 0378-1127(97)00026-1

Lee J, Yoon TK, Han S, Kim S, Yi MJ, Park GS, Kim C, Son YM, Kim R, Son Y (2014). Estimating the carbon dynamics of South Korean forests from 1954 to 2012. Biogeosciences 11: 4637-4650. doi: 10.5194/bg-11-4637-2014

Lemprière TC, Kurz WA, Hogg EH, Schmoll C, Rampley GL, Yemshanov $\mathrm{Y}$, McKenney DW, Gilsenan R, Beatch A, Blain D, Bhatti JS, Krcmar E (2013). Canadian boreal forests and climate change mitigation. Environmental Reviews 21: 293-321. - doi: 10.1139/er-2013-0039

Levy E, Hale SE, Nicoll BC (2004). Biomass expansion factors and root: shoot ratios for coniferous tree species in Great Britain. Forestry 77 (5): 421-430. - doi: 10.1093/forestry/77.5.421

Li Z, Kurz WA, Apps MJ, Beukema SJ (2003). Belowground biomass dynamics in the Carbon Budget Model of the Canadian Forest Sector: recent improvements and implications for the estimation of NPP and NEP. Canadian Journal of Forest Research 33: 126-136. - doi: 10.1139/ x02-165

Lindroth A, Lagergren F, Grelle A, Klemedtsson L, Langvall O, Weslien P, Tuulik J (2009). Storms can cause Europe-wide reduction in forest carbon sink. Global Change Biology 15 (2): 346-355. - doi: 10.1111/j.1365-2486.2008.01719.x

Liski J, Lehtonen A, Peltoniemi M, Eggers T, Muukkonen P, Mäkip R (2006). Carbon accumulation in Finland's forests 1922-2004 - an estimate obtained by combination of forest inventory data with modelling of biomass, litter and soil. Annals of Forest Science 63: 687-697. - doi: 10.1051/forest:2006049

Lull HW, Ellison L (1950). Precipitation in relation to altitude in Central Utah. Ecology 31: 479-484. [online] URL: http://www.jstor.org/stable/19315 07

Luyssaert S, Ciais P, Piao SL, Schulze ED, Jung M, Zaehle S, Schelhaas MJ, Reichstein M, Churkina G, Papale D, Abril G, Beer C, Grace J, Loustau D, Matteucci G, Magnani F, Nabuurs GJ, Verbeeck H, Sulkava M, Van Der Werf GR, Janssens JA, Carboeurope-IP Synthesis Team (2010). The European carbon balance Part 3: forests. Global Change Biology 16: 1429-1450. - doi: 10.1111/j.13 65-2486.2009.02056.x

Metherall AK, Harding LA, Cole CV, Parton WJ (1994). CENTURY Soil Organic Matter Model Environment Technical Documentation, Agroecosystem Version 4.0. Tech Rep No. 4.0, Great Plains System Research Unit, USDA-ARS, Fort Collins, CO, USA, pp. 123. [online] URL: http:// www.nrel.colostate.edu/projects/century/MAN UAL/html_manual/mang6.html

Metsaranta JM, Dymond CC, Kurz WA, Spittlehouse DL (2011). Uncertainty of $21^{\text {st }}$ century growing stocks and GHG balance of forests in British Columbia, Canada resulting from potential climate change impacts on ecosystem processes. Forest Ecology and Management 262: 827-837. - doi: 10.1016/j.foreco.2011.05.016 Mitscherlich EA (1919). Problems of plant growth. Landwirtschaftliche Jahrbucher 53: 167-182.

Nabuurs GJ, Schelhaas MJ (2002). Carbon profiles of typical forest types across Europe assessed with $\mathrm{CO}_{2} \mathrm{FIX}$. Ecological Indicators 1 (3): 213-223. - doi: 10.1016/S1470-160X(02)00007-9

Nabuurs GJ, Schelhaas MJ, Pussinen A (2000). Validation of the European Forest Information Scenario Model (EFISCEN) and a projection of Finnish forests. Silva Fennica 34 (2): 167-179. doi: $10.14214 / s f .638$

Nam KJ, Lee WK, Kim M, Kwak DA, Byun WH, Yu 
H, Kwak H, Kwon T, Sung J, Chung D, Lee SH (2015). Spatio-temporal change in forest cover and carbon storage considering actual and potential forest cover in South Korea. Science China Life Sciences 58 (7): 713-723. - doi: 10.1007/s11427-014-4773-4

Oubrahim H, Boulmane M, Bakker MR, Augusto L, Halim M (2015). Carbon storage in degraded cork oak (Quercus suber) forests on flat lowlands in Morocco. iForest 9: 125-137. - doi: 10.3832/ifor1364-008

Pan Y, Birdsey RA, Fang J, Houghton R, Kauppi PE, Kurz WA, Phillips OL, Shvidenko A, Lewis SL, Canadell JG, Ciais P, Jackson RB, Pacala P, McGuire AD, Piao S, Rautiainen A, Sitch $S$, Hayes D (2011). A large and persistent carbon sink in the World's forests. Science 333: 988993. - doi: 10.1126/science.1201609

Peltoniemi M, Palosou T, Monni S, Mäkipää R (2009). Factors affecting the uncertainty of sinks and stocks of carbon in Finnish forests soils and vegetation. Forest Ecology and Management 232: 75-85. - doi: 10.1016/j.foreco.2006. 05.045

Pilli R, Grassi G, Kurz WA, Smyth CE, Blujdea V (2013). Application of the CBM-CFS3 model to estimate Italy's forest carbon budget, 19952020. Ecological Modelling 266: 144-171. - doi: 10.1016/j.ecolmodel.2013.07.007

SAS Institute Inc. (2003). SAS/STATTM user's guide (version 9.1). Cary, NS, USA, pp. 34.

Schumacher FX (1939). A new growth curve and its application to timber-yield studies. Journal of Forest 37: 819-820.

Segura M, Kanninen M (2005). Allometric models for tree volume and total aboveground biomass in a tropical humid forest in Costa Rica. Biotropica 37: 2-8. - doi: 10.1111/j.1744-7429.2005. 02027.x

Sit V, Poulin-Costello M (1994). Catalogue of curves for curve fitting. Forest Science Research Branch of Ministry of Forest, Victoria, BC, Canada, pp. 110. [online] URL: http://web. unbc.ca/ michael/MOF_Manuals/Bioo4.pdf

Tak K, Chun Y, Wood PM (2007). The South Korean forest dilemma. International Forestry Review 9 (1): 548-557. - doi: 10.1505/ifor.9.1.548 Webb $L$ (1968). Environmental relationships of the structural types of Australian rain forest vegetation. Ecology 49 (2): 296-311. - doi: $10.2307 / 1934459$

Wirth C, Schumacher J, Schulze ED (2004) Generic biomass functions for Norway spruce in Central Europe - a meta-analysis approach toward prediction and uncertainty estimation. Tree Physiology 24: 121-139. - doi: 10.1093/tree phys/24.2.121

\section{Supplementary Material}

Tab. S1 - The whole regression forms to estimate mean tree height, dominant tree height, site index, mean tree $d b h$, and volume.
Tab. S2 - The optimal regression forms to estimate mean tree height, dominant tree height, site index, mean tree $d b h$, and volume by tree species.

Tab. S3 - Parameter estimates of the regression models for mean tree height $(\mathrm{m})$ for each tree species.

Tab. S4 - Site index model used in yield table (Korea Forest Service 2009).

Tab. S5 - Coefficients for site index and dominant tree height equations by tree species developed by the Korea Forest Service (2009).

Tab. S6 - Coefficients for mean $d b h$ equations by tree species developed by the Korea Forest Service (2009).

Tab. S7 - Coefficients for volume ( $\mathrm{V}$ ha $\left.{ }^{-1}\right)$ equations by tree species developed by the Korea Forest Service (2009).

Link: Kim_2040@supplo01.pdf 